\title{
THE EXISTING OF NAQSHBANDI TARIQA AND ITS INFLUENCE ON SOCIO-CULTURAL LIFE OF THE SAKAI PEOPLE IN BENGKALIS REGENCY
}

\author{
Amrizal, Riki Astafi \\ STAIN Bengkalis \\ Jalan Lembaga - Senggoro Bengkalis, Riau, Indonesia \\ E-mail: marifnurch@yahoo.co.id
}

\begin{abstract}
This study aims to determine the development of the Naqshbandi Tariqa and its influence on the socio-cultural life of the Sakai people in the Bengkalis Regency. The findings of this study are that the Naqshbandi Tariqa entered and developed among the Sakai Tribe in several different regions, but not at the same time with varying figures of the carrier. If mapped, there are three main lines (networks), namely the first line of the Ibrahim Caliph in 1912 at Bomban Potani in the area of Bathin Solapan. Second, the path of Sheikh Imam Sabar Al-Kholidi in 1925 in Beringin Village, Talang Muandau area. Third, Caliph Mahmud in 1947 in Tasik Serai. The Sakai Tribe can well accept the presence of the Naqshbandi Tariqa in the Onder region of the Mandau district. It is evidenced by the existence of approximately 11 Suluk houses in the Sakai Tribe domicile today. The teachings of the Naqshbandi Tariqa greatly influenced the socio-cultural life of the Sakai Tribe. Most of them have abandoned the bad habits that have been practiced and become devout Muslims. Islamic values are very thick, coloring their social system, those concerning the method of marriage and family life, social relations, political and government leadership, customs and traditions, and the economy.
\end{abstract}

Keywords:

Muslim communities; Hinduism; Pegayaman village; Menyama Beraya; Balinese exoticism

\begin{abstract}
Abstrak
Penelitian ini bertujuan untuk mengetahui perkembangan Tarekat Naqsyabandiyah dan pengaruhnya terhadap kehidupan sosial budaya masyarakat Suku Sakai di Kabupaten Bengkalis. Temuan penelitian ini bahwa Tarekat Naqsyabandiyah masuk dan berkembang di kalangan masyarakat Suku Sakai di sejumlah wilayah yang berbeda, pada waktu yang tidak bersamaan dengan tokoh pembawa yang berbeda-beda pula. Kalau dipetakan, ada tiga jalur (jaringan) utama, yaitu pertama jalur khalifah Ibrahim tahun 1912 di Bomban Potani wilayah Bathin Solapan. Kedua, jalur Syekh Imam Sabar Al-Kholidi tahun 1925 di Desa Beringin wilayah Talang Muandau. Ketiga, Khalifah Mahmud tahun 1947 di Tasik Serai. Kehadiran Tarekat Naqsyabandiyah di wilayah onder distrik Mandau bisa diterima dengan baik oleh masyarakat Suku Sakai. Hal ini dibuktikan dengan keberadaan lebih kurang sebelas rumah suluk di wilayah domisili Suku Sakai sampai saat ini. Ajaran Tarekat Naqsyabandiyah sangat mempengaruhi kehidupan sosial budaya masyarakat Suku Sakai. Sebagian besar mereka sudah meninggalkan kebiasaan-kebiasaan buruk yang selama ini dipraktekkan dan menjadi Muslim yang taat. Nilai-nilai Islam sangat kental mewarnai sistem sosial mereka baik menyangkut sistem perkawinan dan kehidupan kekeluargaan, tata pergaulan sosial, kepemimpinan politik dan pemerintahan, adat dan tradisi, dan perekonomian.
\end{abstract}

Kata Kunci:

Masyarakat muslim; Hinduisme; Kampung Pegayaman; Menyama Beraya; Eksostisme Bali.

DOI: $10.15575 /$ jw.v4i1.4072

Received: January 25, 2019; Accepted: July 11, 2019; Published: July 30, 2019 


\section{A. INTRODUCTION}

Sakai tribe is one of the indigenous tribes in Bengkalis Regency, Riau Province. Precisely, it is located in Mandau District, Bathin Solapan, Pinggir District, and Talang Muandau. ${ }^{1}$ Many scholars believe that the Sakai tribe is the remnants of the Malay racial group that came to this area. ${ }^{2}$ They mostly settled in the forests, headwaters, and swamps. Their main livelihood is hunting, gathering in the forests, or fishing in rivers. ${ }^{3}$

Sakai people initially professed an animistic belief system, which is a belief in spirit or soul. ${ }^{4}$ In animist belief, many spirits filled not only all natures, but also non-living objects, such as bones and stones. Meanwhile, a dynamism which is a belief that every object around humans has a mysterious power called Mana or Tuah in Indonesian. ${ }^{5}$ However, along with era development, most of them have embraced Islam, although certain animistic and dynamic practices still exist in their societies. So this fact produces negative assessments among Malays in general towards them. Some even think that many of the Sakai people have embraced Islam. However, they still practice a religion of their ancestors that always practice elements of animism, magic power, and about spirits. The essence of the ancestors' religion of Sakai people is a belief in the existence of 'Antu' or supernatural beings around them. Sakai people consider that 'Antu' also has a lifelike human. They are a group and have a residential area. According to the Sakai people, the middle of a jungle is a center of the Antu settlement in which humans have never touched it.

\footnotetext{
${ }^{1}$ Setia Putra and Erdianto Effendi, "Kearifan Lokal Budaya Suku Sakai Terhadap Sumber Daya Perairan Di Kabupaten Bengkalis," Riau Law Journal 1, no. 1 (n.d.): $1-14$.

${ }^{2}$ Annette Hamilton, "Reflections on the 'Disappearing Sakai': A Tribal Minority in Southern Thailand," Journal of Southeast Asian Studies 37, no. 2 (June 15, 2006): 293-314, https://doi.org/10.1017/S0022463406000567.

${ }^{3}$ Zulyani Hidayah, Ensiklopedi Suku Bangsa Di Indonesia (Jakarta: Yayasan Pustaka Obor Indonesia, 2015), 330.
}

Islamization of the Sakai tribe, according to Hamidy UU was carried out by Ulama figures from Naqshbandi Tarekat, ${ }^{6}$ but he did not mention explicitly in his book who were Naqshbandiyah Ulama, who spread Islam there. Though information about them is also essential to know what their role and struggle are in developing Islamic teachings. Through the establishment of Suluk houses in several Sakai tribal settlements, Naqsabandyah Ulamas have indeed Islamized Sakai tribes. The settlements, for example, include Pematang Pudu Village, Air Jamban, Batin Sobangar Duri 13, Balai Pungut, and Muara Basung with the number of hundreds of followers and dozens of caliphs and deputies (Badal) to this time. The existence of Naqshbandi tariqa in the Sakai tribe community, which still exists and survives until now, is an interesting phenomenon to behold. Because in some populations of other indigenous tribes in Bengkalis Regency such as Akit Tribe in the Rupat District, Rupat Utara, Bantan, and Bengkalis, the teachings of the tariqa did not develop. Meanwhile, tariqa teaching significantly affects their sociocultural life, as reflected in their daily attitudes and behavior. Besides, many scholars firmly believe that the process of Islamization among the Sakai tribe was carried out by the leaders of Naqshbandi Tariqa, who had a connection with Sheikh Abdul Wahab Rokan in Babussalam Langkat, North Sumatra. In the process of developing Islam through the teachings of tariqa, of course, they face many dynamics and challenges from local communities that are 
thick with these animistic traditions. After all, sociologically, as stated by Soejono Soekanto, belief systems such as ideology, philosophy of life, and others are elements of culture that are difficult to accept for a society. ${ }^{7}$ Therefore, the nature and characteristics of society will always suspect foreign ideologies that enter to its community. The process of accepting new doctrines in society will certainly cause social friction even though it occurs in a small intensity.

This study uses a qualitative approach with the analysis of the theory of social change Ferdinand Tonnies (1855-1936), which divides society into two groups, namely Gemeinschaft (a group or association) and Gesellschaft (a society or modern society). ${ }^{8}$ The study was conducted for three months from September to November 2018 by taking districts of Mandau, Pinggir, Inner Solapan, and Talang Muandau Bengkalis Regency as research locations. Researchers have interviewed tariqa leaders, tariqa congregations, religious leaders, and traditional leaders.

Previous studies relating to Sakai Tribe has conducted by many researchers. First, Parsudi Suparlan (1993) entitled Orang-orang Sakai di Riau: Masyarakat Terasing dalam Masyarakat Indonesia. ${ }^{9}$ This research highlighted more aspects of Sakai people's history in Riau and their socio-cultural conditions. Starting from their environment, livelihoods, economy and daily life, kinship systems, belief systems, leadership, and other aspects of culture. Second,

Cipta Pratama Tarigan, Zahirman, Ahmad Eddison (2012) entitled Pengaruh Modernisasi terhadap Tata Cara Adat Pernikahan Suku Sakai di Desa Pinggir Kecamatan Pinggir Kabupaten Bengkalis. ${ }^{10}$ Following the title, this

\footnotetext{
${ }^{7}$ Soerjono Soekanto, Sosiologi Suatu Pengantar (Jakarta: Raja Grafindo Persada, 2006), 169.

${ }^{8}$ Damsar and Idrayani, Pengantar Sosilogi Pedesaaan (Jakarta: Kharisma Putra Utama, 2016), 42.

${ }^{9}$ Supardi Suparlan, Orang Sakai Di Riau, Masyarakat Terasing Dalam Masyarakat Indonesia (Jakarta: Yayasan Obor, 1995).

${ }^{10}$ Cipta Pratama Tarigan and Ahmad Eddison Zahirman, Pengaruh Modernisasi Terhadap Tata Cara
}

research only highlights the influence of modernization in Sakai Marriage Customary Procedures, and based on this study result, the influence is very dominant. Third, Fatma Yulia (2008) entitled Pandangan Masyarakat Suku Sakai terhadap Sistem Pewarisan Menurut Hukum Adat di Kecamatan Mandau, Kabupaten Bengkalis, Provinsi Riau. ${ }^{11}$ The results showed that the views of Sakai people towards the inheritance system based on Customary Law in Mandau district, Bengkulu Regency, lead to a system of integration among inheritance systems that are collectiveindividual. The distribution carried out by the inheritance system mentioned above is motivated by family or kinship nature, which shows a mixture of matrilineal and parental. Besides, there is also a tendency of Indigenous Peoples who have begun to be influenced by Islamic Law.

These previous studies of the Sakai tribe have not yet found specific research relating to the development of Islam in the Sakai tribe through Naqshbandi Tariqa. Although Parsudi Suparlan's research revealed a glimpse of the Islamization process in Mandau, his research focused more on the sociological and cultural aspects of Sakai people. Likewise, other studies discuss more similar things.

This research aims to find out how the Sakai community accepts the process of Islam and Naqshbandi tariqa, how the development is, and how it affects their socio-cultural life. Through this study, a description of history and development of Naqshbandiyah tariqa among the Sakai tribe will be obtained through the applied Islamization pattern and also the extent to which the teachings of Naqshbandiah tariqa influence their daily attitudes and behavior.

Adat Pernikahan Suku Sakai Di Desa Pinggir Kecamatan Pinggir Kabupaten Bengkalis (Pekanbaru, 2012).

${ }^{11}$ Fatma Yulia, "Pandangan Masyarakat Suku Sakai Terhadap Sistem Pewarisan Menurut Hukum Adat Di Kecamatan Mandau, Kabupaten Bengkalis, Provinsi Riau," Jurnal Ilmiah Advokasi 2, no. 1 (2014): 14-25. 


\section{B. RESULT AND DISCUSSION}

\section{The Sakai Tribe and Islamization in Indonesia}

Indonesian society has long been the target of the Islamization process. As a religious missionary, Islam obligates its people to spread Islamic teachings to others both individually and communally.

In the Minang tribe, West Sumatra, Islam was first estimated in the 7 th century, ${ }^{12}$ and in 674, Arab communities have lived on the east coast of Sumatra island. In addition to trading, they slowly brought Islam to Minangkabau or West Sumatra highlands now through rivers that flow east of Sumatra island, such as Batang Hari. The development of Islam in West Sumatra became very rapid after the Aceh sultanate was ruled by Sultan Alauddin Riayat Syah al-Kahar, who succeeded in expanding his territory to almost the entire west coast of Sumatra. So in the 13th century, Islam began to enter Tiku, Pariaman, Air Bangis, and other coastal areas of West Sumatra. Islam then also came to Minangkabau highland called "Darek." In the Darek region at that time stood the Pagaruyung kingdom, which the kingdom began to have Islamic influence around the 14th century. Before Islam was widely accepted, people around the kingdom center from some archaeological evidence showed that they had embraced Buddhism and Hinduism, especially before entering in the 7 th century. ${ }^{13}$

Among Javanese, many scholars believe that Islam has come in the 11th century brought by merchants from Arabia. ${ }^{14}$ Its development was more rapid after the presence of Wali Songo at the beginning of the 15th century and the establishment of the Demak Islamic kingdom. ${ }^{15}$

\footnotetext{
${ }^{12}$ Nikki R Keddie, "Islam and Society in Minangkabau and in the Middle East: Comparative Reflections," Sojourn: Journal of Social Issues in Southeast Asia 2, no. 1 (1987): 1-30.

${ }^{13}$ Sifullah, Sejarah Dan Kebudayaan Islam Di Asia Tenggara (Yogyakarta: Pustaka Pelajar, 2010), 15.

${ }^{14}$ Theodore Gauthier Th. Pigeaud and H. J. de Graaf, Islamic States in Java 1500-1700 (Dordrecht: Springer Netherlands, 1976), https://doi.org/10.1007/978-94-0157187-6.
}

In Dayak tribe Kalimantan, Islam entered at the end of the 15th century through two channels. The first is the Malacca route through Islamic kingdoms of Malacca and Pasai that was mainly in the West Kalimantan region (Sukadana) in the early 16th century. ${ }^{16}$ The second path is through Java since the establishment of the Demak Kingdom. The spread of Islam in Kalimantan indeed cannot be separated from trade routes because, in Kalimantan itself, there were trading ports in the Hindu-Buddhist Kingdoms era -primarily Kalimantan also provided reliable commodities such as pepper at that time. But Islam has not been entirely accepted on a massive basis by Kalimantan people. Spreading Islam momentum occurred since Prince Samudera adhered Islam in 1526.

In the Bugis tribe in Sulawesi, Islamization took place in the 16th century brought by three scholars from Minangkabau, namely Khatib Tunggal Datuk Makmur, or known as Datuk Ribandang in South Sulawesi, Khatib Sulung Datuk Sulaiman, known as Datuk Patimang, Sheikh Nurdin Ariyani known as Datuk RiTiro. The development of Islam in Bugis' land increasingly rapid growth after King Gowa XIV officially embraced Islam in 1605 , which finally changed its name to Sultan Alauddin. ${ }^{17}$

From some notes about Islamization in several regions in Indonesia, Ulamas, both local and regional, have spread Islamic doctrines in Indonesia. Through trade activities and even political approaches (power), many kings embraced Islam, and this made its people did the same thing until the kingdom became an Islamic kingdom.

Not much different Islamization pattern also occurs in Sakai tribe. Sakai tribe is one of the

\footnotetext{
${ }^{15}$ Alwi Shihab, Islam Pertama Dan Pengaruhnya Hingga Kini Di Indonesia, Islam Sufistik (Bandung: Mizan, 2001), 8.

${ }^{16}$ Arfah Ibrahim, "Islam in Southeast Asia," ArRaniry: International Journal of Islamic Studies 5, no. 1 (2018): 40-52.

${ }^{17}$ Musyrifah Sunanto, Sejarah Peradaban Islam Indonesia (Jakarta: Raja Grafindo Persada, 2007), 27.
} 
inland tribes in Bengkalis Regency, Riau Province, which came from Pagaruyung, Batusangkar, West Sumatra, and from Mentawai. ${ }^{18}$ The Sakai people are mainly in several points and locations within the Bengkalis Regency, Riau Province. Their presence today is precisely in Mandau District, Bathin Solapan, Pinggir, and Talang Muandau. In 1984 it was estimated that their population was around 6,500 people or approximately 1,400 households. Meanwhile, based on data from Bengkalis Regency social service, the number of Sakai people in the Bengkalis Regency in 2013 was 3,353 households with 11,081 people.

Initially, the traditional Sakai community embraced animism and dynamism. They have known cosmology that is different from new religions such as Hinduism, Islam, and Christianity. Cosmologically, the Sakai people believe that nature has five levels, which is the highest level is a ghost. ${ }^{19}$

Islam entered to Sakai tribe estimated in 1912 brought by Ulama of Naqshbandiyah Tariqa, who came from Basilam, North Sumatra, which was caliphs who took Bai'at with Shaykh Abdul Wahab Rokan.

In its early era, Islamization among Sakai tribe faced a formidable challenge, in which the Sakai tribes on average refused and resisted because the presence of Islam was considered by them to threaten their traditions and customs. However, after making various efforts, tariqa scholars have succeeded in Islamizing the minds of the Sakai tribe, and all their tribal members followed it and provided further guidance regarding Islamic teachings, an established institution of the tariqa.

\footnotetext{
${ }^{18}$ Supardi Suparlan, Orang Sakai Di Riau, Masyarakat Terasing Dalam Masyarakat Indonesia (Jakarta: Yayasan Obor, 1995), 72.

${ }^{19}$ Saputra and Syahrial De, Kearifan Lokal Yang Terkandung Dalam Upacara Tradisional Kepercayaan Masyarakat Sakai-Riau (Tanjung Pinang: BPNST, 2010), 29-30.
}

\section{The Sakai Tribe and Naqshbandi Tariqa Development}

Tariqa can be interpreted as a system of living together and togetherness in diversity as an effort to spiritualize understanding and practice the teachings of Islam towards the achievement of Ma'rifatu'l-lah. In this perspective, this formulation can be interpreted as a collective effort in tazkiyah al-nafs efforts in the framework of religious interiorization. ${ }^{20}$

Experts more widely use the term Tariqa in Sufism. In this case, Mustafa Zahri said that the path is a path or a guide in performing worship according to the teachings exemplified by Prophet Muhammad and carried out by his friends, tabi'in and tabi'in tabi'in from generation to generation to the teachers in a chain until in our time. More specifically, Sufiyah tariqa means the system in the framework of conducting soul training, ridding oneself of the despicable qualities, and filling them with praiseworthy qualities and multiplying the $d h i k r$ sincerely solely to expect to meet with and be spiritually united with God. The path in tariqa, among others, is continuously in remembrance or remembering God, and continuously avoiding something that forgets God. ${ }^{21}$

In the case, Harun Nasution said that tariqa was the path that a Sufi had to take to aim to be as close as possible to God. ${ }^{22}$ Meanwhile, according to Hamka said that between the creature and Khaliq, there is a journey of life that people must take or what so-called tariqa. ${ }^{23}$

Based on some previous understanding about tariqa, tariqa is a spiritual path for a Sufi which contains practices of worship and others with the theme of mentioning the name of Allah and its attributes accompanied by deep appreciation. The practice in this tariqa aims to

\footnotetext{
${ }^{20}$ A. Rivay Siregar, Tasawuf Dari Sufisme Klasik Ke Neo-Sufisme (Jakarta: Raja Grafindo Persada, 2002), 263.

${ }^{21}$ Abuddin Nata, Akhlak Tasawuf (Jakarta: Raja Grafindo Persada, 2008), 270.

${ }^{22}$ Harun Nasution, Falsafah Dan Mistisisme Dalamm Islam (Jakarta: Bulan Bintang, 1979), 89.

${ }^{23}$ Hamka, Tasawuf Perkembangan Dan Pemurniannya (Jakarta: Pustaka Panjima, 1984), 104.
} 
get the closest (spiritually) possible relationship with God. Further development, tariqa is not only limited to the path (teaching) but implies an organization that has shaykhs, ritual ceremonies, and certain forms of remembrance. ${ }^{24}$

The tariqa has the purpose of learning about personal mistakes and deficiencies in conducting acts of worship or in interacting with the community. It is also learning how to correct their mistakes by cleansing liver diseases through guidance from a teacher who has reached the perfection of the tariqa and is competent in the method of treating liver diseases. $^{25}$

According to Shaykh Sholeh Basalamah, tariqa is essentially inviting people to take advantage of the time to always recite Allah. According to him, the primary purpose of tariqa is to invite Muslims to dhikr to Allah, because sometime after the Messenger of Allah left the people, Islam began far from remembrance, whereas in Al-Qur'an commands humans to always remembrance, to get a calm and happy heart. ${ }^{26}$ Meanwhile, according to Khalil, the purpose of the Tariqa is to find a way to draw closer to Allah. To be able to find and take this path, adherents must learn the shortcomings, mistakes, and sins that they do, then make improvements. $^{27}$

The learning process in tariqa relates to the relationship between teacher and student. The teacher in tariqa is called Murshid or Shaykh, and his representative is called a caliph. While his followers are called Salik (students). Whereas tariqa is called ribath or zawiyah or taqiya.

Each tariqa has certain religious practices or teachings, institutional symbols, rules, and other ceremonies. According to the provisions

\footnotetext{
${ }^{24}$ Ecep Ismail, “Landasan Qur'ani Tentang Zikir Dalam Ajaran Tarekat," Syifa Al-Qulub 1, no. 2 (2017): 195-201.

${ }^{25}$ William Stoddart and Reynold A Nicholson, Süfism: The Mystical Doctrines and the Idea of Personality (London: Bloomsbury Publishing, 1998).

${ }^{26}$ Mustain Yusuf, Yety Rochwulaningsih, and Singgih Tri Sulistiyono, "Roles of KH. Abdul Wahab Sya'roni and Syaikh Ali Bin Ahmad Basalamah in the
}

of tariqat in general, that a Shaykh is very determining towards his students. The presence of a student in front of his teacher is like a dead or helpless carcass of nothing. Because tariqa is a way to be close to Allah, the person who performs the path must carry out Shari'a, and the student must fulfill the following elements:

a) Studying religious law knowledge.

b) Observing and trying as the best they can to follow in the footsteps and the teacher. The students have to carry out his teacher's orders and do not abandon his prohibition.

c) Do not look for relief in charity to achieve ultimate perfection.

d) Do and fill time as efficiently as possible with all the wirid and prayers for the stabilization and specificity in achieving higher maqamat (stations).

e) Curb the lust to avoid mistakes that tarnish charity.

The characteristics of a tariqa are the characteristics generally held by each group, while in the form of charity and wirid are different. ${ }^{28}$ By following tariqa education, a salik can understand and realize his weaknesses and mistakes. Besides, he can understand and realize the existence of his heart disease and how to handle it based on the direction of his teacher. Because someone is challenging to know and realize their shortcomings. Therefore, he needed someone who was an expert at that, the murshid teacher. In addition to interacting with the murshid teacher, a salik can improve his behavior through the uswah method, which is watching and imitating the teacher's manners all the time. Because social or environmental situations have a significant influence on character formation. ${ }^{29}$

The development of Naqshbandi tariqa among the Sakai tribe society is inseparable

Development of Thariqoh Tijaniyah in Jatibarang, Brebes, Central Java," Indonesian Historical Studies 1, no. 2 (2017): 117-24.

${ }^{27}$ Totok Jumantoro and Samsul Munir Amin, Kamus Ilmu Tasawuf (Wonosobo: Amzah, 2005), 245.

${ }^{28}$ Nata, Akhlak Tasawuf, 272.

${ }^{29}$ Abdul Qadir Isa, Haqaiqah Al-Tasawuf, ed. Qishtini Pers (Jakarta, 2014), 22. 
from the role of Siak Kingdom Sultanate, Sri Indrapura, ${ }^{30}$ which provides an opportunity for religious groups to preach as well as in educational activities. Based on this fact, the Sultan gave a massive opportunity for the growth and development of tariqa understanding, so that Naqshbandi tariqa was the most significant religious organization and spread to various mainland areas after centuries of development in Riau. ${ }^{31}$

The map of Naqshbandi tariqa development during Siak Sultanate was firstly on Bagan Siapiapi District and Siak District, both of which have now become Rokan Hilir and Siak Sri Indrapura Districts. From the Bagan SiapiSiapi Districts, Naqshbandiyah tariqa caliphs then spread to various areas around it. The Bagan Siapi-api District, in which the Naqshbandi tariqa used it as a basis of its development, placed 44 teachers who had received tariqa education from Tuan Guru Sheikh Abdul Wahab Rokan in Basilam Langkat, North Sumatra. ${ }^{32}$ Sultan Siak's efforts to recruit the Naqshbandi tariqa had two purposes. First, to teach in various educational institutions, and second, for the specific purpose of developing tariqa teaching. Based on the religious teacher regulation in 1930, 57 teachers were given permission to teach in three districts, 44 each in Bagan Siapi-api District, 8 in Pekanbaru District, and 5 in Selat Panjang District, and 29 of them were teachers who taught tariqa. ${ }^{33}$

From Bagan Siapi-api District, Naqshbandiyah tariqa caliphs continued to search following the Rokan river channel and visited various community settlements. The relentless struggle of the caliphs has yielded results. It has been providing a distinctive color to the Islamic practice in the Riau Malay community. It is because the teachings of Naqshbandi tariqa have now spread to various regions of mainland Riau, especially in addition to Islam. Naqshbandiyah tariqa might have initially entered to Mandau region under Siak Sultanate. It is along with the Islamization of the hinterland around 1912. ${ }^{34}$ Syekh Abdul Wahab Rokan granted the Caliph Ibrahim to Islamize and develop the tariqa in Bagan Siapiapi district. A district that borders directly Onder Mandau district, which has been as the settlement area of the inland people (Sakai), an egalitarian group of people, living in isolation and seclusion in the upper reaches of the river, on the edges of springs and marshes.

Another version of the tariqa history in the region is the writing of Muhammad Yatim Bathin Iyo Banso bin Khalifah Usman. He explained that Abdul Wahab Rokan sent the Caliph Ibrahim with four of his friends (Datuk Imam Nempang, Datuk Lobai Dewi, Datuk Husein, and Datuk Lekak) to preach Islam in the land of Sakai. ${ }^{35}$

Then in 1925, Syeikh Imam Sabar alKholidi developed the Naqshbandi tariqa in Beringin village, ${ }^{36}$ which is currently in Talang Muandau district. To obtain permission (legality) from Sultan Siak, in 1931, he applied Sultan Siak Kingdom Sri Indrapura to develop the teachings of the tariqa in Mandau and surrounding areas. Sheikh Imam Sabar AlKholidi submitted this permit application because the Mandau region was under the authority of the Siak Sri Indrapura kingdom. ${ }^{37}$

\footnotetext{
${ }^{30}$ Ahmad Yusuf, Sultan Syarif Kasim II, Raja Terakhir Kerajaan Siak Sri Indrapura (Pekanbaru: Pemerintah Daerah Propinsi Riau, 1992), 42.

${ }^{31}$ Suparlan, Orang Sakai Di Riau, Masyarakat Terasing Dalam Masyarakat Indonesia, 194.

${ }^{32}$ Fuad Said, Syekh Abdul Wahab Tuan Guru Babussalam (Medan: Yayasan Pembangunan Babussalam, 1976).

${ }^{33}$ M. Arrafie Abduh, "Peran Tariqa Naqshbandi Khalidiyyah Syekh Abdul Wahab Rokan," Alfikra, Jurnal Ilmiah Keislaman 11, no. 2 (2012).
} 
After examining the request of Shaykh Imam Sabar and examining the sciences he would develop, Sultan found that the teachings of tariqa were following Shari'ah and did not cause opposition to the kingdom. Then Sulthan permitted Sheikh Imam Sabar to develop his teachings in the Mandau region. ${ }^{38}$ The Dipertoean Besar Sjarif Qasim Abdoel Jalil Sjarifoeddin Ibnoe Almarhoem Soelathan Hasjim Negeri Siak Nomor: 76 Sanah 1333 has issued the permit. ${ }^{39}$

In 1947, Chaliph Mahmud also developed the teachings of Naqshbandiyah Tariqa. He was a delegation of Sheikh Abdul Wahab Rokan, who was assigned to develop the tariqa in Tasik Serai, West Serai Tasik, Bagan Benio, which is currently in Talang Muandau district. Then it was continued by his students Khalifah Muhammad Yatim, Khalifah Subur, and Khalifah Yakin. ${ }^{40}$

Whereas around 1957, Naqshbandiyah tariqa was also developed by Sheikh Muhammad Taib from Babussalam Langkat North Sumatra and later developed his tariqa teachings in of Siarang-Arang village which at that time included in Rokan Hilir Regency. Then continued by his pupil Sheikh Ramadan who founded the First Suluk house in Babussalam Simpang Karang Anyer in 1971. Furthermore, in 1978 moved to Buluh Kasab Pematang Pudu Village in $1978 .^{41}$ Moreover, his student Syekh Sulaiman in Petani Village, which is currently in Mandau District.

The period difference of Naqshbandiyah tariqa development was due to the pattern of the delegation of Caliphate authority to become a rigorous Murshid teacher, meaning that not all Naqshbandiyah tariqa students had the authority to develop tariqa and lead Suluk and also because of the broad area of Mandau

History of the Development of the Naqshbandi Tariq in the Kec. Mandau in Balai Pungut Village Written on 16 September 1989," 1989.

${ }^{38}$ Usman.

${ }^{39}$ Copy of Sulthan Siak Permit Written According to the Original by Sheikh Usman.

${ }^{40}$ Khalifah Darwis, interview by Riki Astafi, Duri, on October 13, 2018. district onder and where Sakai tribe lived scattered at several points so that it is technically a bit difficult in the process of dissemination. Besides, there was a stagnation process so that there was a period of development pause or emptiness even though Sakai people had primarily converted to Islam. Then only after the caliph's students took Suluk in Babussalam, Langkat, and returned to Mandau, the process of developing Tariqah continued.

In the early period of Naqshbandiyah tariqa presence in this region, which was brought by Caliph Ibrahim in 1912, Sakai Batin made a fight against him in the form of a challenge of fighting spiritually (mystically). As quoted in a famous story among Muslim community in Mandau where around 1917 Tungkek nonompek (Dubalang Bomban Potani) which is said to be immune to sharp weapons challenged Mr. Shaykh Khalifah Ibrahim to circumcise them with an agreement if they could not be circumcised then given sanctions that caliph Shaykh Ibrahim together with four of his friends will be killed. This challenge did not weaken the spirit of Mr. Sheikh Khalifa Ibrahim in da'wah. With the permission of Allah, Sheikh Khalifah Ibrahim succeeded in circumcising them by using the back of a knife that was started by Bathin Teba (Strong Bathin). After this incident, Batin ordered all their descendants to convert to Islam. This story is reinforced again by Hamka Riau, who further explained that it was the event that caused the Sakai tribe people to highly respect Naqshbandiyah Caliphs because they believed that the caliphs had higher or stronger knowledge than them. ${ }^{42}$

Similar resistance was also faced by Sheikh Imam Sabar, the developer of Naqshbandiyah

\footnotetext{
${ }^{41}$ Khalifah Yusuf (Penasehat Rumah Suluk Babussalam), interview by Riki Astafi, House of Suluk, on October 11, 2018.

${ }^{42}$ Hamka (Mandau Community Leaders), interview by Riki Astafi, Pondok Pesantren Hubbul Wathon Duri, on October 13, 2018
} 
tariqa in the second period of 1925 when developing Islamic teachings in Beringin village and its surroundings. He got many obstacles or challenges that came from Minas tribe, Bathin Takah group, Penaso tribe, Bathin Genggang group, Belutu tribe, Bathin Babut group. However, this obstacle did not make Shaykh Imam Sabar step down. By gradually, they eventually embraced Islam and renounced their beliefs.

This Islam entrance to the Sakai tribe does not necessarily make them abandon their old customs and culture. The tariqa institutions carried out further development. The caliphs, through an effective approach, invited them to enter the tariqa and follow the Sulyadah Suluk. As Shaykh M. Yusuf, a pupil of Shaykh Imam Sabar, came to their homes to persuade them to follow Suluk and bear all their costs while following him. ${ }^{43}$ This approach gets sympathetic to Sakai people so that many of them enter the tariqa and participate in activities in Suluk houses for a specified period.

Likewise, in the third period of tariqa development brought by the Khalifah Shaykh Makmud around 1947 in the Tasik Serai region, Tasik Serai Barat, Bagan Benio and Sheikh Muhammad Taib around 1957 in Pematang Pudu and Petani regions. Both get not many different challenges. It is just that these periods are not as severe as in the previous two periods. Most of the Sakai people in this period had adhered Islam, but their Islam was still incomplete because many of them practiced their old habits before converting to Islam.

The first Suluk house founded by Caliph Ibrahim was not known for sure. However, the Suluk house, which was founded by Syekh Sulaiman's grandson, was in Rangau Belading around the 1930s. In contrast, the Suluk house was founded by Shaykh Ramadan or known as Bujangganti, in Babussalam around 1956. Then around 1977, moved to Buluh Kasab, Pematang Pudu Village because in the old location became one of the oil exploration areas by Caltex. ${ }^{44}$ After Sheikh Ramadan died, Chaliph

\footnotetext{
${ }^{43}$ Khalifah Kasri, interview by Riki Astafi, Desa Muara Basung, on October 12, 2018.
}

Basyir, Chaliph Kasim, Chalipha M. Darawi, and Caliph Bukhari continued the activities at Suluk house. They were pupils of Sheikh M. Yusuf from Muara Basung. In contrast, the first Suluk house, which was established by Shaykh Imam Sabar, was on the edge of Balai Pungut Village around 1931, which was named Rumah Suluk al-Tahrim. After that, he founded the mosque, which is now the footprint of the Baldatun mosque. Dozens of worshipers took the tariqa from him came from the family and surrounding communities of the Sakai tribe and Mandau Malay tribe. During the leadership of Sheikh Imam Sabar, his Suluk House has produced more than fifty caliphs. They are Caliph Usman, Caliph Zakaria, Caliph Muhammad Ali, Caliph M. Yusuf, Caliph Yunus, Caliph Muhammad, Caliph Umar, Caliph Daud, Caliph Yahya, Caliph Ismail (RIP) and Caliph Muhammad Nur (Caliph Muhammad), Caliph Muhammad, Caliph Umar, Caliph Daud, Caliph Yahya, Caliph Ismail (RIP) and Caliph Muhammad Nur (RIP).

The development of Naqshbandiyah tariqa by Shaykh Imam Sabar was then continued by his students, Shaykh Usman, his pupil, as well as his son, at Balai Pungut to continue the construction of the Suluk house that his father had established after 1960. Then Sheikh M. Yusuf in Muara Basung and its surroundings and Terengganu. The next Caliph Yahya in Kuala Penaso and Caliph Zakaria in Kandis, Samsam, Minas, and surrounding areas.

Under the leadership of Sheikh Usman alTahrim, the Suluk house has produced more than 50 caliphs. After Shaykh Usman, Chaliph M. Ali continued the Suluk house in Balai Pungut and produced 13 caliphs. Caliph Idris produced 11 caliphs, and finally, the Caliph Fachri produced one caliph. Among the students of Sheikh Usman, named Khalifah Muzani, built a Suluk house in Air Jamban Village.

Sheikh M. Yusuf built Suluk house in Muara Basung around 1980 under the name Khairul

\footnotetext{
${ }^{44}$ Zainal Arifin, interview by Riki Astafi, House of Suluk, on October 11, 2018.
} 
Amal. Under his leadership, Sheikh M. Yusuf guided more than one hundred congregations and resulted in several caliphs, including Shafi'i Caliph, M. Nur Caliph, Ali Hanafiah Caliph, H.M. Syarif Caliph, and Kasri Caliph. For now, Suluk Khairul Amal's house is under the leadership of Shafi'i Caliph, the grandson of Sheikh M. Yusuf.

The first Suluk houses of the Naqshbandi tariqa via the Caliph Mahmud route were in Serai Wangi, which was continued by Caliph M. Yatim. In Tasik Serai, it was continued by Caliph Subur and in West Tasik Serai, which was continued by Khalifah Yakin.

The recruitment pattern of Naqshbandiyah tariqa students from the Sakai tribe who had converted to Islam by the caliphs or murshid teachers was not selectively made because there were no educational institutions other than the tariqa to foster them after converting to Islam. For the caliphs or murshid teachers, the important thing was that they want to follow Suluk first and then strengthen their religious foundation and religious practice. So they become devout Muslims and renounce their previous habits. The persuasive efforts of the caliphs added the not-so-strict requirement to persuade people to enter the tariqa and follow the Suluk. It made them interested in and impressed with Naqshbandi tariqa.

The existence of Islam developed through the institution of tariqa can be well received by Sakai people for these following factors:

Through promoting a more friendly, persuasive, and moderate cultural approach, the caliphs spread and developed the Naqshbandiyah tariqa among the Sakai tribe. They did not use an approach to violence and coercion.

The caliphs personally showed a high piety attitude and always provided assistance and social services to the community. This attitude makes the community feel sympathetic and interested in converting to Islam.

a) The similarity of ideas and characters between the beliefs of Sakai people and the teachings of tariqa that both emphasize aspects of mysticism is only the difference if the mysticism of the Sakai tribe is built based on animism and dynamism. In contrast, the Naqshbandi mysticism based on Islamic teachings.

b) Islamic universal theology system does not believe in boundaries of space and time. In contrast to the belief system that developed previously at that time, that was localization.

The mystical power of Islam based on Sufistic teachings, can "defeat" the power of local mystics.

\section{Suluk House and Naqshbandi Tariqa}

The existence of Suluk houses, Naqshbandi tariqa now exists in several regions. In Mandau District, there are two Suluk houses located in Pematang Pudu Village and Suluk houses on Jalan Kayangan Air Jamban Village. In Bathin Solapan District, there is one Suluk house, that is, the Suluk house in Petani Village. In Pinggir District, there are four Suluk houses, namely Darussalam Suluk house, Nurussalam Suluk house, al-Tahrim Suluk house, and the Khairul Amal Suluk house. Then in Talang Muandau District, there are four Suluk houses, namely the Suluk house in Beringin Village, the Suluk house in Kuala Penaso, the Suluk house in Serai Wangi, the Suluk house in Tasik Serai, the Suluk house in West Tasik Serai under the leadership of the caliph Yakin.

In these Suluk houses, the congregation of tariqa periodically carries out the sulyadah, which is guided by the caliphs. Some take the sulyadah for ten days, twenty days, and forty days - usually held in the months of Muharram and Ramadan. Some carry out other than that month. The pilgrims fully bear the cost of living during the Sulukadah Suluk. At the same time, as this sulyadah ritual, pilgrims also usually make a pilgrimage to the teacher's grave. In addition to Suluk riyadah, the followers held tawajuh activities twice a week, which usually takes Tuesday night and Friday night. There are also ratib togak in the mosque. Besides, there is also haul, but these activities have not been carried out lately.

In the early days of the establishment of Suluk houses, the enthusiasm of the community to take Naqshbandi tariqa was quite 
high. In general, they are divided into two groups; some take tariqa only and those who take tariqa and follow Suluk. ${ }^{45}$ Along with the times, the interest of the community to take the tariqa has declined. This fact resulted in tariqa not experiencing additional significant. Among the contributing factors are mental (psychological) unpreparedness, busyness with various worldly activities, and also economic factors. ${ }^{46}$ Besides, the interruption of the leadership of the tariqa, which had an impact on the emptiness of the caliph or deputy as a murshid teacher, caused the activities of the sulyadah Suluk to cease, causing some Suluk houses to be closed or there were no Suluk activities anymore.

Lately, most of the followers of Naqshbandi tariqa in the areas of Mandau, Batin Solapan, Pinggir, and Talang Muandau come from older people who indeed have long taken the tariqa. Meanwhile, their enthusiasm to attend Suluk riyadah and tawajuh routine activities has diminished. Their number is also getting smaller because many people have died. While many young people are not interested in entering the tariqa and following Suluk riyadah, this is because of the development of situations and conditions that have undergone changes and the increasing number of mediums for the community to study religion and the establishment of Islamic educational institutions in several places. On average, children from the Sakai tribe community have tasted the world of education, both general and madrasah, or pesantren even to college. ${ }^{47}$ Touch with the modern world that allows them to access various information and knowledge through a variety of existing facilities makes them prefer approaches and methods that are easier and more modern than traditional and conservative in strengthening their religious knowledge and practice capacity.

\footnotetext{
${ }^{45}$ Khalifah H. M. Syarif, interview by Riki Astafi, Desa Muara Basung, on October 12, 2018.

${ }^{46}$ Khalifah Kasri, interview by Riki Astafi, Desa Muara Basung, on October 12, 2018.
}

This fact makes the development of the tariqa as one of the institutions of learning and practice of traditional Islamic teachings through a series of spiritual practices that characterize Sufism outside of school So that the existence of Suluk houses and followers of Naqshbandi tariqa has diminished. Only a few Suluk houses still exist today, such as the Suluk House in Pematang Pudu, the Suluk House in Air Jamban Village, the Suluk House in Petani, the Suluk al-Tahrim House in Balai Pungut, the Khairul Amal Suluk House in Muara Basung. The rest have been closed because there are no more Suluk activities and disconnections of the caliph or murshid teacher who has the authority (diploma) to lead the Suluk. This situation is the concern of several tariqa leaders in seeing the future of Naqshbandi tariqa and the remaining Suluk houses in the districts of Mandau, Bathin Solapan, Pinggir, and Talang Muandau. It seems that sooner or later, the remaining Suluk houses will suffer the same fate as Suluk houses that are no longer functioning.

\section{Naqshbandi Tariqa and Socio-Cultural Life of the Sakai Tribe}

Starting from the theory of social change proposed by Ferdinand Tonnies (1855-1936), which divides society into two groups, namely Gemeinschaft (a group or association) and Gesellschaft (a society or modern society). Gemeinschaft arises from within the individual, and there is a desire to have a relationship or relationship based on similarity in desire and action. Individuals, in this case, are interpreted as adherents and supporters of social forces connected with friends and relatives (family), through which they build emotional relationships and interactions of one individual with other individuals. While Gesellschaft, as a contrast, signifies changes that develop, behave rationally in an individual in their daily lives, social change among the

\footnotetext{
${ }^{47}$ Hamka (Mandau Community Leaders), interview by Riki Astafi, Pondok Pesantren Hubbul Wathon Duri, on October 13, 2018.
} 
Sakai tribe can apply the framework of Tonnie's theory. Sakai tribe was initially built based on a family and kinship system and traditional values that are powerful binding their daily lives and behavior. The instinct to live together is in the Koentjara Ningrat language called collective life. Collective life has the characteristics of a system of division of labor, cooperative activities, and communication processes. Unlike the lives of other creatures, the collective life of human beings is constructed based on the power of reason, through learning. ${ }^{48}$

Their knowledge and mindset are elementary, and mystical and occult things filled them. They adhere to the belief systems of animism and dynamism. They have known cosmology that is different from the new religions of Hinduism, Islam, and Christianity. Regarding cosmology, the Sakai people believe that nature has five levels in which the highest level is a spirit. Its name is various, including ghosts (antu, antui), fairies, gnome, and all ancestral spirits. At the lowest level is level one, namely water, soil, and air. They believe spirits can affect humans, so there must be a relationship between humans and spirits. Fine creatures also live in large trees, so that when cutting down large trees, ceremonies are also expelled. They also know the land ruler as land antu. They also recognize forest land that is sacred and inhabited by spirits and ancestral spirits called puaka. ${ }^{49}$ They believe that the person who has just died is still in the spirit around the residence so that the family left behind will go across the river because the spirit is considered unable to cross the river. The spirit of the deceased, also called antu, can be ordered for protection or specific interests (such as panghulubalang in the Batak community). Moreover, they also recognized the magical sanctions' existence, which was feared and obeyed and made one of the guidelines for life in the group.

\footnotetext{
${ }^{48}$ Koentjaraningrat, Pengantar Ilmu Antropologi (Jakarta: Rineka Cipta, 2002), 137.
}

After Islam entered and developed among the Sakai tribe brought by Naqshbandiyah Ulema clerics, there has been a significant change in the aspects of their beliefs and social life after getting the teaching and coaching by the Naqshbandiyah tariqa caliphs in the Suluk houses. The bad habits that they have been practicing, such as the practice of shamanism and medicine called thinking, are no longer practiced. Their penchant for eating naguih, a type of pig that is small and lizards, has been abandoned. They are increasingly obedient in carrying out the commands of the Islamic religion. Islamic teachings have always been the primary reference for them in living their daily lives.

Islamic values are very thick, coloring their social systems related to the marriage system and family life, social relations, political and government leadership, customs and traditions, and the economy. The marriage system and their family relations are built based on marriage law and family law in Islam, which emphasizes the legitimacy according to Islamic law, the existence of rights and obligations, and guarantees and protection. Their social relations based on the principles that uphold ukhuwah Islamiyah. Political and government leadership emphasizes the role of the tariqa teacher or the tariqa teacher as a reference for deciding essential and strategic matters. The principles of Islamic teachings harmonized with their customs and traditions. When there are elements who blamed with syara', it will be eliminated. When in line with syara', it will be done. In carrying out economic ventures or trying to make ends meet, they refer to economic practices that are justified by the Shari'a.

The tariqa teacher or caliph became a figure that was highly respected and glorified among them. Their role is considered quite important in social life, not only as religious leaders or guides of religious ceremonies in society or completing religious obligations but also as a

\footnotetext{
${ }^{49}$ Saputra and De, Kearifan Lokal Yang Terkandung Dalam Upacara Tradisional Kepercayaan Masyarakat Sakai-Riau, 29-30.
} 
place to ask questions and consult on religious, social issues. Besides, there are tariqa or caliph teachers who can help problems faced by the community, especially in the treatment of diseases or other problems.

\section{CONCLUSION}

The study revealed that Naqshbandi tariqa entered and developed among the Sakai tribe community through three periods: first, around 1912 brought by Caliph Ibrahim, the second around 1925 developed by Shaykh Imam Sabar Al-Kholidi and the third around 1947 developed by Caliph Mahmud.

The development of Naqshbandi tariqa has shown a significant progression. The increasing number of followers of the tariqa and the establishment of several Suluk houses in the four districts, Mandau, Batin Solapan, Pinggir, and Talang Muandau, proves it. However, its development has stagnated and even declined recently. It is due to the absence of a significant increase in the number of followers. Moreover, many suluk houses are no longer functioning due to the emptiness of the tariqa leadership (murshid teacher or deputy). Only little suluk houses are still working and predominantly by older people.

The teachings of Naqshabandiah tariqa has a positive impact on the social life of the Sakai people. They can abandon their followers' bad habits. They are increasingly obedient in carrying out the commands of the Islamic religion. Islamic teachings have always been the primary reference for them in their daily lives. Islamic values are very thick, coloring their social systems related to the marriage system and family life, social relations, political and government leadership, customs and traditions, and the economy.

\section{REFERENCES}

Abduh, M. Arrafie. "Peran Tariqa Naqshbandi Khalidiyyah Syekh Abdul Wahab Rokan." Alfikra, Jurnal Ilmiah Keislaman 11, no. 2 (2012).

Bakhtiar, Amsal. Filsafat Agama, Wisata Pemikiran Dan Kepercayaan Manusia. Jakarta: Raja Grafindo Persada, 2007.
Bruinessen, M M van. "After the Days of Abû Qubays: Indonesian Transformations of the Naqshbandiyya-Khâlidiyya." Journal of the History of Sufism 5 (2007): 225--251.

Damsar, and Idrayani. Pengantar Sosilogi Pedesaaan. Jakarta: Kharisma Putra Utama, 2016.

Hamidy, U. U. Pengislaman Masyarakat Sakai Oleh Tarekat Naksyahbandiyah Babussalam. Pekanbaru: Pusat Kajian Islam dan Dakwah, Universitas Islam Riau, 1992.

Hamidy, UU. Jagad Melayu Dalam Lintasan Budaya Di Riau. Pekanbaru: Bilik Kreatif Press, 2011.

Hamilton, Annette. "Reflections on the 'Disappearing Sakai': A Tribal Minority in Southern Thailand." Journal of Southeast Asian Studies 37, no. 2 (June 15, 2006): 293-314.

https://doi.org/10.1017/S002246340600056 7.

Hamka. Tasawuf Perkembangan Dan Pemurniannya. Jakarta: Pustaka Panjima, 1984.

Hidayah, Zulyani. Ensiklopedi Suku Bangsa Di Indonesia. Jakarta: Yayasan Pustaka Obor Indonesia, 2015.

Ibrahim, Arfah. "Islam in Southeast Asia." ArRaniry: International Journal of Islamic Studies 5, no. 1 (2018): 40-52.

Isa, Abdul Qadir. Haqaiqah Al-Tasawuf. Edited by Qishtini Pers. Jakarta, 2014.

Ismail, Ecep. "Landasan Qur'ani Tentang Zikir Dalam Ajaran Tarekat." Syifa Al-Qulub 1, no. 2 (2017): 195-201.

Jumantoro, Totok, and Samsul Munir Amin. Kamus Ilmu Tasawuf. Wonosobo: Amzah, 2005.

Keddie, Nikki R. "Islam and Society in Minangkabau and in the Middle East: Comparative Reflections." Sojourn: Journal of Social Issues in Southeast Asia 2, no. 1 (1987): 1-30.

Koentjaraningrat. Pengantar Ilmu Antropologi. Jakarta: Rineka Cipta, 2002.

Nasution, Harun. Falsafah Dan Mistisisme Dalamm Islam. Jakarta: Bulan Bintang, 1979.

Nata, Abuddin. Akhlak Tasawuf. Jakarta: Raja 
The Existing of Naqshbandi Tariqa and Its Influence on Socio-Cultural Life of the Sakai People in Bengkalis Regency

Grafindo Persada, 2008.

Pigeaud, Theodore Gauthier Th., and H. J. de Graaf. Islamic States in Java 1500-1700. Dordrecht: Springer Netherlands, 1976. https://doi.org/10.1007/978-94-015-7187-6.

Putra, Setia, and Erdianto Effendi. "Kearifan Lokal Budaya Suku Sakai Terhadap Sumber Daya Perairan Di Kabupaten Bengkalis." Riau Law Journal 1, no. 1 (n.d.): 1-14.

Said, Fuad. Syekh Abdul Wahab Tuan Guru Babussalam. Medan: Yayasan Pembangunan Babussalam, 1976.

Saputra, and Syahrial De. Kearifan Lokal Yang Terkandung Dalam Upacara Tradisional Kepercayaan Masyarakat Sakai-Riau. Tanjung Pinang: BPNST, 2010.

Schebesta, Pater P, and Charles Otto Blagden. "The Jungle Tribes of the Malay Peninsula." Bulletin of the School of Oriental and African Studies 4, no. 2 (1926): 269-78.

Shihab, Alwi. Islam Pertama Dan Pengaruhnya Hingga Kini Di Indonesia, Islam Sufistik. Bandung: Mizan, 2001.

Sifullah. Sejarah Dan Kebudayaan Islam Di Asia Tenggara. Yogyakarta: Pustaka Pelajar, 2010.

Siregar, A. Rivay. Tasawuf Dari Sufisme Klasik Ke Neo-Sufisme. Jakarta: Raja Grafindo Persada, 2002.

Soekanto, Soerjono. Sosiologi Suatu Pengantar. Jakarta: Raja Grafindo Persada, 2006.

Stoddart, William, and Reynold A Nicholson. Süfism: The Mystical Doctrines and the Idea of Personality. London: Bloomsbury Publishing, 1998.

Sunanto, Musyrifah. Sejarah Peradaban Islam Indonesia. Jakarta: Raja Grafindo Persada, 2007.

Suparlan, Supardi. Orang Sakai Di Riau, Masyarakat Terasing Dalam Masyarakat Indonesia. Jakarta: Yayasan Obor, 1995.

Syah, Abdullah. "Tarekat Naqshbandiyah Babussalam Langkat." In Sufisme Di Indonesia. Jakarta: Balitbang Agama Departemen Agama, 1978.

Tarigan, Cipta Pratama, and Ahmad Eddison
Zahirman. Pengaruh Modernisasi Terhadap Tata Cara Adat Pernikahan Suku Sakai Di Desa Pinggir Kecamatan Pinggir Kabupaten Bengkalis. Pekanbaru, 2012.

Usman, Syech. "Notes on Syech Usman Bin Syech Imam Sabar Al-Kholidi Naqshbandi Concerning a Brief History of the Development of the Naqshbandi Tariq in the Kec. Mandau in Balai Pungut Village Written on 16 September 1989," 1989.

Yatim, Muhammad. "A Personal Note from the Top of the Molayu Sakai Tribe, Written on February 8, 2012," 2012.

Yulia, Fatma. "Pandangan Masyarakat Suku Sakai Terhadap Sistem Pewarisan Menurut Hukum Adat Di Kecamatan Mandau, Kabupaten Bengkalis, Provinsi Riau." Jurnal Ilmiah Advokasi 2, no. 1 (2014): 1425.

Yusuf, Ahmad. Sultan Syarif Kasim II, Raja Terakhir Kerajaan Siak Sri Indrapura. Pekanbaru: Pemerintah Daerah Propinsi Riau, 1992.

Yusuf, Mustain, Yety Rochwulaningsih, and Singgih Tri Sulistiyono. "Roles of $\mathrm{KH}$. Abdul Wahab Sya'roni and Syaikh Ali Bin Ahmad Basalamah in the Development of Thariqoh Tijaniyah in Jatibarang, Brebes, Central Java." Indonesian Historical Studies 1, no. 2 (2017): 117-24.

\section{INTERVIEW}

Khalifah Darwis, interview by Riki Astafi. Duri. October 13, 2018.

Khalifah Yusuf (Penasehat Rumah Suluk Babussalam), interview by Riki Astafi. House of Suluk. October 11, 2018.

Hamka (Mandau Community Leaders), interview by Riki Astafi. Pondok Pesantren Hubbul Wathon Duri. October 13, 2018.

Zainal Arifin, interview by Riki Astafi. House of Suluk. October 11, 2018.

Khalifah Kasri, interview by Riki Astafi. Desa Muara Basung. October 12, 2018.

Khalifah H. M. Syarif, interview by Riki Astafi. Desa Muara Basung. October 12, 2018. 